\title{
Maya Deren: A Prologue
}

\author{
Harmony Bench
}

E

qual parts artist, theorist, entrepreneur, and evangelist, it is difficult to measure Maya Deren's lingering, pervasive, and sometimes forgotten influence on experimental cinema, but this issue of The International Journal of Screendance tries to do just that. With more film projects abandoned than completed, however, it would be incorrect to assume that Deren's impact was exclusively or even primarily an aesthetic one. Deren was a game-changer, to be sure, but her impact on filmmaking was felt as much through her actions and words, which legitimated experimental cinema in an American context, as it was felt through her films. Deren biographer Catrina Neiman notes that Deren "put as much effort into cultivating the audience for cinema as an art form as she did into film-making itself." It seems that no one ever told Deren that there were things she couldn't do, that there were rules and protocols to be followed. Or if they did, she paid no attention. In this way, Deren paved the way for artists coming after her, forging an American avant-garde cinema. She gained recognition from institutions that had not previously acknowledged film as an artistic medium: she was the first to receive a fellowship from the Guggenheim Foundation for "Creative Work in the Field of Motion Pictures" in 1947. She lectured widely on her films and on her theories about film. She screened and distributed her own work. Just as she repeatedly used the techniques of filmmaking to open up new and unexpected terrains for movement, splicing and juxtaposing environments across which a performer could navigate (for example, in At Land and A Study in Choreography for Camera) in her life, Deren made space for experimentalism in an era that favored films of an educational, documentary, or commercial entertainment variety.

Chastising filmmakers for what she termed their "criminal negligence" of cinema's magical and transformative properties, ${ }^{2}$ Deren argued that the only authentic use of film was one that "creates a reality and itself constitutes an experience." ${ }^{3}$ Though Deren's imagery seems influenced by the visual arts world —-then, as now, the field most proximate to experimental cinema-Deren's aesthetic structures are undoubtedly grounded in the poetic logics of the performing arts. Of course Deren's films frequently featured dancers as well as other artists. As a result of Deren's dance background and study of performance, she developed a cinema that was more magical than surreal (she took great care to distinguish her work from surrealists), more dream than unconscious, more ritual than intellectual. But when Deren realized that she could not creatively reinterpret the danced rituals of Haitian Voudoun (Deren's spelling) in film as choreographer Katherine Dunham (with whom Deren worked in 1941) had done for the stage, Deren became an anthropologist, writing the definitive Divine Horsemen: The Living Gods of Haiti in 1953.

In her films, Deren emphasized a choreographic aesthetic, regardless of whether or not onscreen movement could be classified as "dancing," and she denounced what she saw as the typical Hollywood style of treating film as though it were simply another stage: "In most 
dance films the dancer, knowing little of the possibilities of camera and cutting, works in terms of theatrical choreographic integrity...The usual unsatisfactory result is neither... good film nor good dance."4 Choreographers, assuming a fixed-front audience, imported proscenium framing and spacing into the film medium, while cameramen distorted choreography by moving through dance ensembles. The more successful a dance was for presentation onstage the less successful it was onscreen, resulting, Deren intimates, in a misshapen, incoherent entity. Indeed, both Busby Berkeley and Fred Astaire, who had clearly-articulated visions of how to present dance onscreen, sustained the integrity of one art form - either cinema or dance-at the expense of the other. Berkeley, for example, intended for his choreographies to be seen from 360 degrees, eschewing any notion of a fixed-front viewer. Adapting his theatrical style to the screen, Berkeley had his dancers create short bits of dance material, which he then arranged according to his shooting needs. He peered down on the dancing women in his signature overhead shots or traveled across arrays of spread-eagle legs, indifferent to choreography as such. Astaire, in contrast, limited camera movement and duplicated theatrical perspective. He choreographed lengthy sequences, which were generally filmed as full-body shots with few changes in camera angle and with very minimal editing. In an interview, John Winge quotes Astaire as saying, "Either the camera will dance or I will. But both of us at the same time-that won't work. A moving camera will make the dancer look like [he is] standing still."5 Both men rejected the hybridity that Deren sought in her own films.

In contrast to the popular dance styles represented in Hollywood movies, Deren turned to American modern dance, and later to contemporary ballet, when she incorporated dance in her films. Given Deren's insistence upon the specificity of the film medium, it is somewhat curious that she should welcome dance and develop an explicitly choreographic, and not merely a kinetic, approach to cinema. But she found in dance a "magical" way of moving that interested her as a filmmaker, ${ }^{6}$ and she advocated the development of choreographed motion specific to the film medium: "If film is to make any contribution to the realm of movement, if it is to stake out a claim in an immeasurably rich territory, then it must be in the province of film-motion, as a new dimension altogether of movement."7 Deren's fusion of dance and film resulted in a form she called "film-dance," which, she asserted, is "so related to camera and cutting that it cannot be 'performed' as a unit anywhere but in this particular film" — — an idea that is practically gospel in many corners of the screendance community. Employing the filming and editing techniques available to her, Deren interrogated the spatio-temporality of a screenic body. She reimagined the space of dance and the time of movement, replacing choreographic repetitions with cinematic ones, experimenting with slow motion and reverse action, and exploring the psycho-visual import of photographic negative. She choreographed space as well as the bodies and objects in it. She pushed the aesthetic and ontological elasticity of both dance and cinema, encouraging if not forcing their recreation, redefinition, and reevaluation. Deren discovered a unique way to film movement and opened up choreography as a concept to be explored cinematically.

The choreographic register is not the register that resounds most strongly in this issue of The International Journal of Screendance. This collection of essays was inspired by the presentations and discussions that took place at the Maya Deren: 50 Years On retrospective and symposium held at the British Film Institute in October of 2011. Focusing on how 
Deren's work continues to reverberate some 50 years after her death, the authors in these pages emphasize continuities and residual effects observable in contemporary experimental cinema and the continued usefulness of Deren's film theory and practice. In the six essays that make up the bulk of this special issue on Maya Deren, three main themes emerge: Deren's own first principles of filmmaking and the centrality of the poetic and magical in the structure and effect/affect of her films; comparative analyses of Deren's films and those of contemporary filmmakers; and finally, Deren's unique modes of working and theorizing that have been rearticulated in more recent scholarship.

Sophie Mayer discovers residual elements of Deren's aesthetic in Jane Campion's 2003 film In the Cut, particularly in the "vertical" structuring of both films and the doubling of their protagonists. Crucially, Mayer locates Deren's Ritual in Transfigured Time historically at the conclusion of WWII, and Campion's In the Cut in the aftermath of September 11, 2001. Read in the context of global violence, Mayer argues that Deren and Campion share what film theorist Elena del Rio calls a "micropolitics of the powers of affection" that allows them to comment on "grief and vulnerability." With Deren as a consistent touch-point, Mayer attends to the use of dance in Campion's film, which, like Ritual, "unites dance and death," and in so doing, "grieves the geopolitical conflict... and counters it." Silvina Szperling similarly discusses Deren's influence among South American artists as seen especially through the work of German-born Argentinean experimental artist and filmmaker Narcisa Hirsch, who was also interviewed for this issue of The International Journal of Screendance. Paying particular attention to Hirsch's 1999 film Rumi, Szperling emphasizes the quest of each filmmaker to render poetic and emotional states in visual form. Each filmmaker, Szperling notes, believed that "experimental films with their non-linear structure and dream-like transitions could visually transpose the experiential qualities of lyric poems."

The poetic remains at the fore for Sarah Keller as well, who supplements poetry with rhythm in her account, and for Lucy Reynolds, who emphasizes the magic embedded in Deren's poetic onscreen transformations. Keller specifically places Deren within a dance context, noting that Deren's exposure to dance and her work with notable dancers and choreographers infused her films with a sense of rhythm not native to the medium of film, but rather created where dance and film mutually intersect with motion. Indeed, Keller argues, rhythm can be viewed as a signal principle underlying Deren's interests across poetry, cinema, dance, and anthropology. But it is ultimately poetry that gives Deren's films their shape, in Keller's analysis, for it is the poetic form, which dance shares, that eschews linear and narrative causality in favor of felt impressions linking images together in otherworldly rhythmic ecologies. Such alternate rhythms lend themselves to explorations of the marvelous, and Reynolds encourages readers to attend to the spaces of imagination Deren's films open up in their relationship to film magic. Reynolds emphasizes that Deren creates strange new worlds, which, though magical, maintain their own internal logic. Reading Deren's film theories alongside those of Jean Epstein, Reynolds suggests that Deren's relationship to myth, ritual, and magic situates her more closely to what Laura Mulvey calls the technological uncanny than the psycho-sexual "shocks" of Surrealists, whom Deren rejected.

Claudia Kappenberg similarly plumbs the poetic in Deren's films as logical visual structure commensurate with written forms of poetry, but crucially different from language as such. Kappenberg particularly examines Deren's theorization of verticality and horizontality in films as they relate to time, emotion, and action. Here, horizontality refers to causality, the 
teleology of dramatic action, and the progression of a narrative. Verticality, in contrast, refers to the suspension of action and slowing of time that enables a filmmaker to drill down into different layers of emotion, coloration, technique, reflection, or other considerations that recede into the background when attention is primarily focused on an unfolding plot. These Kappenberg likens to French philosopher Gilles Deleuze's articulation of the movement-image and the time-image, arguing that despite the negative reception of Deren's theory of form, Deleuze legitimates the structures Deren describes.

But as Andrew James notes, it was not only Deren's film theories that are in need of recuperation. James suggests that Deren's interdisciplinarity and her emphasis on collaboration has rendered her less visible to film scholarship, including feminist critics engaged in writing women back into the history of filmmaking. When scholars do consider Deren's work, Alexander Hammid's central role in Deren's most influential film Meshes of the Afternoon, and collaborators on other films become obscured in favor of Deren-as-auteur. To better understand Deren's work and contributions to filmmaking, scholars must apply the seemingly recent notions of interdisciplinary and collaboration to her artistic process.

Together, these essays go a long way to invite Maya Deren's work to the table of contemporary cinematic experimentation and scholarship, but they also collectively focus on the films with which audiences and readers are most familiar, namely Meshes of the Afternoon, Ritual in Transfigured Time, and, to a lesser extent, A Study in Choreography for Camera and At Land. The authors gathered here remain mostly silent on the films Meditation on Violence, made with Chao-Li Chi, and The Very Eye of Night, made with Antony Tudor. Much remains to be gleaned from her unfinished and/or unreleased films as well: The Witch's Cradle, made with Marcel Duchamp; Medusa, made with Jean Erdman; Ensemble for Somnambulists; and Seasons of Strangers. Divine Horsemen: The Living Gods of Haiti, posthumously edited on Deren's behalf by Cherel and Teiji Ito and an important work in visual anthropology, is a notable absence in these discussions. In the second issue of The International Journal of Screendance, Elinor Cleghorn picked up a few of these threads and added a few others in her article "Manus Operandi: Film, Sculpture, Choreography." There, she analyzed The Witch's Cradle alongside Richard Serra's experimental film Hand Catching Lead. Both films focus intimately on the movement vocabulary of hands and fingers - catching, or attempting to catch, in Serra's film, and entangling and disentangling a disconcertingly agential string in Deren's. Both films are also principally informed by sculpture: Serra's own practice as a sculptor, and the surrealist sculptures amongst which Witch's Cradle was filmed. Though unintentional, dividing Deren across issues in this way is quite apropos for a filmmaker who was a specialist in discovering ways to use bodies, motion, and cinematic magic to create a bridge between shots. Cleghorn's essay functions similarly, connecting this issue with the previous one.

Yet, our interest in Deren is by no means exhausted by including Cleghorn with the six other essayists. Rather, we see more conversations opening in front of us-and, of course, to the sides and behind, above and below. No book, journal issue, or collection can hope to tackle all of an artist's work. To Andrew James's point, however, the fact that Deren moved from poetry to film, incorporated dancers and a choreographic sensibility into her work, collaborated with many artists, wrote prolifically, and pursued her fascination with ritual and magic into the field of anthropology, means that no single biographical narrative or skillful film interpretation will grasp the complexity of Deren's life, aesthetics, or ideas. No 
life or body of work can ever be packaged neatly, but Deren in particular was simply too interdisciplinary to be reduced to a few films and a couple of theories, as any attempt to understand Deren's lingering influence must inevitably do. In a way, Deren's corpus reflects the poetic realities she created in individual films. There is no logical connection that leads from one film to the next, no life story that reaches its inevitable conclusion with Deren's premature death —only a felt connection that carries us from one to another like Deren's sandaled feet swinging from landscape to landscape in Meshes of the Afternoon. Deren isolates and explores gaps in space, time, and consciousness that she straddles cinematically. But in bridging here and there, now and then, observer and participant, self and loss of self, Deren always points to the gulf between them. It is there that Deren's significance will continue to be sought out and discovered: in the in-between-frames.

\section{Notes}

1. Clark, et al., Legend Vol. 1 Part 2, 4.

2. Deren, "Cinema as an Independent Art Form," 345.

3. Deren, "Cinema as an Art Form," 22 (emphasis in original).

4. Deren, "Choreography for the Camera," 220-221.

5. Winge 8 .

6. Deren, "Creating Movies," 132.

7. Deren, Anagram, 48.

8. Deren, "Choreography for the Camera," 222.

9. The International Journal of Screendance 2 (Spring 2012): 129-139.

\section{References}

Clark, VèVè, Millicent Hodson, and Catrina Neiman. The Legend of Maya Deren: A Documentary Biography and Collected Works. Vol. 1, Part 2: Chambers (1942-47). New York: Anthology Film Archives/Film Culture, 1988.

Cleghorn, Elinor. "Manus Operandi: Film, Sculpture, Choreography." The International Journal of Screendance 2 (Spring 2012): 129-139.

Deren, Maya. An Anagram of Ideas on Art, Form, and Film. In Maya Deren and the American Avant-Garde, edited by Bill Nichols, 267-322. Berkeley: Univ. of California Press, 2001.

. "Choreography for the Camera." In Essential Deren: Collected Writings on Film by Maya Deren, edited by Bruce McPherson, 220-224. Kingston: Documentext, 2005.

. "Cinema as an Art Form." In Collected Writings on Film by Maya Deren, edited by Bruce McPherson, 19-33. Kingston: Documentext, 2005.

. "Cinema as an Independent Art Form." In The Legend of Maya Deren: A Documentary Biography and Collected Works. Vol. 1, Part 2: Chambers (1942-47), edited by VèVè Clark, Millicent Hodson, and Catrina Neiman, 345-349. New York: Anthology Film Archives/Film Culture, 1988.

. "Creating Movies with a New Dimension: Time." In Essential Deren: Collected Writings on Film by Maya Deren, edited by Bruce McPherson, 131-138. Kingston: Documentext, 2005.

Winge, John. "How Astaire Works." Theater Today (1950): 7-9. 


\section{Media}

At Land (1944). Dir. Maya Deren, with Hella Heyman and Alexander Hammid. 16mm, 15:00 min., b\&w, silent. Meditation on Violence (1948). Dir. Maya Deren, with Chao-li Chi. 16mm, 13:00 min., b\&w, sound.

Meshes of the Afternoon (1943). Dir. Maya Deren and Alexander Hammid. 16mm, 14:00 min., b\&w, silent. Music by Teiji Ito added in 1959.

Ritual in Transfigured Time (1945-1946). Dir. Maya Deren and Frank Westbrook, with Hella Heyman and Rita Christiani. 16mm, approx. 15:00 min., b\&w, silent.

A Study in Choreography for Camera (1945). Dir. Maya Deren, with Talley Beatty. 16mm, approx. 3:00 min., b\&w, silent.

The Very Eye of Night (1952-1955). Dir. Maya Deren and Antony Tudor, with the Metropolitan Opera Ballet School. $16 \mathrm{~mm}, 15: 00 \mathrm{~min} ., \mathrm{b} \& \mathrm{w}$, sound. Music by Teiji Ito.

\section{Unfinished Films}

Ensemble for Somnambulists (1951). Dir. Maya Deren, with Cynthia Barrett and Brian Macdonald. 16mm, approx. 7:00 mins, b\&w, silent.

Haitian Film Footage (1947-1955). Released as Divine Horsemen: The Living Gods of Haiti (1985). Dir. Maya Deren, with Haitian Voudoun practitioners. Edited by Teiji and Cherel Ito. $16 \mathrm{~mm}$, approx. 4 hours, b\&w, silent and sound recordings.

Medusa (1949). Dir. Maya Deren, with Jean Erdman. 16mm, approx. 10:00 min., b\&w, silent.

Season of Strangers (a.k.a. Haiku Film Project) (1959). 16mm, approx. 58:00 min., b\&w, silent.

The Witch's Cradle (1943). Dir. Maya Deren, with Marcel Duchamp and Pajorita Matta. 16mm, fragments approx. 13:00 min., b\&w, silent.

\section{Further Reading and Viewing}

Clark, VèVè, Millicent Hodson, and Catrina Neiman. The Legend of Maya Deren: A Documentary Biography and Collected Works. Vol. 1, Part 1: Signatures (1917-42). New York: Anthology Film Archives/Film Culture, 1984.

The Legend of Maya Deren: A Documentary Biography and Collected Works. Vol. 1, Part 2: Chambers (1942-47). New York: Anthology Film Archives/Film Culture, 1988.

Essential Deren: Collected Writings on Film by Maya Deren. Ed. Bruce McPherson. Kingston: Documentext, 2005.

Deren, Maya. Divine Horsemen: The Living Gods of Haiti. Kingston: McPherson, 1983.

. "Film in Progress. Thematic Statement." Film Culture 39 (Winter 1965): 11-17.

."Notes on Ritual and Ordeal." Film Culture 39 (Winter 1965): 10.

"A Statement on Dance and Film." Dance Perspectives 30 (Summer 1967): 10-13.

In the Mirror of Maya Deren (2002). Dir. Martina Kudlácek. Perf. Miriam Arsham, Stan Brakhage, Chao Li Chi, Rita Christiani, Maya Deren, Katherine Dunham, and Alexander Hammid. Zeitgeist Video. DVD.

Invocation: Maya Deren (1987). Dir. Jo Ann Kaplan. Narr. Helen Mirren. Perf. Stan Brackage, Joseph Campbell, Maya Deren, Alexander Hammid, Hella Heyman, Teiji Ito, Jonas Mekas, Jana Sheldon, Amos Vogel, and Marcia Vogel. Jackson, Renata. The Modernist Poetics and Experimental Film Practice of Maya Deren (1917-1961). Edwin Mellen Press: Lewiston, 2002.

Maya Deren and the American Avant-Garde. Nichols, Bill, ed. Berkeley: University of California Press, 2001. 